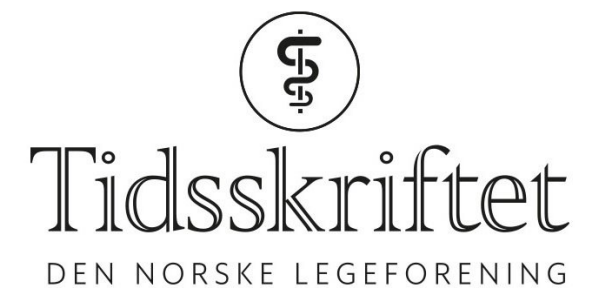

DEN NORSKE LEGEFORENING

\title{
Håp - selv når det nesten ikke finnes
}

PERSONLIGE OPPLEVELSER

ANONYM

Forfatteren er anonym, men vedkommendes identitet er kjent for redaksjonen.

Pasienter med dødelige diagnoser trenger håp. Legens innstilling kan bety mye for å finne mening med tilværelsen når tiden er begrenset.

Legens blikk flakker mellom pasienten - min kone - og arket han har i hånden. Han har fått den utakknemlige oppgaven å formidle svaret på vevsprøven til pasienten, som nylig er operert for en svulst. Han har aldri snakket med henne tidligere.

Legen begynner med å beskrive diagnosen, en alvorlig kreftsykdom. Så fortsetter han med kort beskrivelse av det begrensede behandlingstilbudet, før han avslutter med å snakke om hvor lei seg han er, og hvor vanskelig det er å måtte gi en slik beskjed. Deretter ser han igjen ned i bordplaten før han trykker oss raskt i hånden. Vi går ut av rommet - sønderknuste begge to - og uten håp i sikte.

\section{Ikke legens opplevelse, men pasientens}

Det viktige her er ikke legens ubehjelpelige bemerkning om eget ubehag, men at han ikke tok utgangspunkt i pasientens situasjon - tilsynelatende helt uten forståelse for hva en slik beskjed innebærer for den og dem det gjelder.

Hva får så oss leger til å oppføre oss som guder som tror vi vet når noen skal dø, og tror at vi vet at livet frem til døden vil bli ulevelig? Essensen i den beskjeden vi fikk var at livet kom til å bli så ille at det var like godt å dø med en gang. Slik virket i hvert fall samtalen på oss. Ikke ett ord om at livet, til tross for diagnosen, fortsatt var noe å leve for. Pasienten fikk inntrykk av at det livet som sto foran henne neppe ville vare mer enn få måneder, selv om det ikke ble sagt.

Min kone levde i to år etter denne første beskjeden. Det er betydelig lenger enn median overlevelse for denne svulsttype. I denne perioden måtte hun mobilisere mye mental kraft for å leve livet maksimalt og samtidig forberede seg på døden. Jeg vet det ville vært lettere for henne dersom legen som formidlet diagnosen samtidig kunne ha gitt henne en eller annen form for håp. For hva visste legen om denne unike pasientens sykdom, eller hennes evner til å mobilisere håp, til å fylle livet med aktiviteter, og til å bidra til mening med trening, kosthold og mental mobilisering?

\section{Så godt som mulig}

Leger som ikke evner å installere håp ved dødelig sykdom, burde ikke overbringe diagnoser. Med håp mener jeg ikke falske forhåpninger knyttet til mirakuløse behandlingsformer, 
men håp om å få et så godt og så langt liv som mulig. Leger må kunne si noe om at noen pasienter vil leve lengre enn gjennomsnittet, og at mange lever ganske gode liv til tross for at de har en uhelbredelig sykdom. Mye kan være friskt og gi mening, selv i en kropp med veldig syke organer.

I de to årene som pasienten fikk leve etter at diagnosen var fastslått, var hun i kontakt med over 15 leger, og alle disse passet på å si noe som ga håp eller trøst. De støttet hennes aktive holdning til det hun kunne gjøre: trene, reise, være sammen med familien så langt kreftene rakk. Ikke i strid med realitetene, men innenfor en medisinsk virkelighet, for denne unike pasienten, på dette tidspunktet i forløpet. Det støttet henne til å gjøre riktige ting for å opprettholde funksjon, og mening fra time til time, dag til dag.

Min erfaring er likevel at historien fra det første møtet ikke er enestående. Jeg følger selv opp pasienter med spredning av uhelbredelig kreft. De forteller om lignende historier. De kan stå på legemidler som har positive effekter på helsen, som forlenger deres liv, og som får svulster til å bli mindre. Det er pasientene lykkelig for, men de undrer seg over at noen av legene som følger dem ikke ser ut til tro på disse effektene. De gleder seg ikke med pasienten, men gir heller inntrykk av at dette er for godt til å være sant.

\section{Respekt for usikkerheten}

Det vil aldri bli mulig for leger å fastslå hvor lenge pasienter med alvorlig kreftsykdom vil leve. Vi kan predikere, estimere, anta, tro og tippe, og kan synes vi er flinke hvis vi treffer godt i et estimat. Vi bør ha større respekt for usikkerheten, og la den komme pasienten til gode. Å installere håp er ikke en urealistisk optimisme, men å støtte pasienten i deres bestrebelser i å finne måter å fortsette å leve med mening. Å ikke installere håp stenger for dette.

I etiske regler for leger står det i paragraf 1: «En lege skal verne menneskets helse. Legen skal helbrede, lindre og trøste. Legen skal hjelpe syke til å gjenvinne sin helse.» Vår families opplevelse var på utsiden av dette idealet.

Det er vi leger som sitter med kunnskapen om pasientenes sykdom. De er prisgitt våre vurderinger, og vår bruk av ord. De lytter intenst til det vi sier, og forsøker å forstå hva det betyr. Dødelige diagnoser må ikke bli absolutte dødsdommer - så gode dommere er vi ikke.

Publisert: 25. mars 2019. Tidsskr Nor Legeforen. DOI: 10.4045/tidsskr.18.0826

(C) Tidsskrift for Den norske legeforening 2020. Lastet ned fra tidsskriftet.no 